\title{
Interviewing and Hiring Practices in Brazilian Academia: Proposals Towards Improvement
}

\author{
Eva O.L. Lantsoght ${ }^{1,2, * \mathbb{C}}$, Miguel Abambres ${ }^{3,4}$, Tiago Ribeiro ${ }^{5} \mathbb{C}$ and Ana Sousa ${ }^{5} \mathbb{C}$ \\ 1 Department of Engineering Structures, Civil Engineering and Geosciences, Delft University of Technology, \\ 2628 CD Delft, The Netherlands \\ 2 Politécnico, Universidad San Francisco de Quito, Quito 170901, Ecuador \\ 3 R\&D, Abambres' Lab, 1600-275 Lisbon, Portugal \\ 4 Escola de Tecnologias e Engenharia, Instituto Superior de Educação e Ciências (ISEC-Lisboa), \\ 1750-142 Lisbon, Portugal \\ 5 Independent researcher, 1000 Lisbon, Portugal \\ * Correspondence: e.o.l.lantsoght@tudelft.nl
}

Received: 29 May 2019; Accepted: 9 August 2019; Published: 14 August 2019

\begin{abstract}
Though Brazilian academia claims equality, the sector has largely been referred to as non-meritocratic, and academic hiring is still inward-oriented. The Lattes platform, a public curricular information system, reflects elements of this protectionism. This article assesses two 'obsessions' in Brazilian academia: the 'mandatory' Lattes $\mathrm{CV}$, and the assessment criteria and procedures in public tenders for faculty positions. The current situation is introduced to the reader, and the shortcomings of these methods and their effect on academia in Brazil are analyzed. The following improvements are proposed: (1) evaluations in public tenders based on a candidate's CV, interview, and a sample lecture, (2) removing the Lattes CV as a mandatory format, and (3) using platforms such as Microsoft Academic, Google Scholar, ORCID or ResearcherID for curricular information. With these recommendations, Brazil can move towards a more open and international-oriented academic hiring system.
\end{abstract}

Keywords: Brazilian academia; interviewing for faculty positions; Lattes CV; meritocracy

\section{Introduction}

Meritocracy is a system in which individuals make progress and gain the fruits of their own efforts. It uses pre-established criteria to assess people according to their performance, regardless of their seniority and networks. According to Barbosa [1] and Pinheiro [2], Brazil is a flawed meritocracy, since it does not promote a fair assignment of its citizens' own labor efforts, and endangers the entrepreneurial spirit by imposing bureaucracy and inefficient rules. Back in 1996, Barbosa [1] stated that public tenders employ unsuitable assessors and assessment methods, and/or allow biased results due to personal relationships. A 2016 Brazilian self-descriptive work of fiction titled " $3 \%$ ", mocked the current situation and showed a dystopia where merit can only be measured if one formulates a particular range of tests, and then administers them to every member of society in the same way [3]. The complex public tenders today have been developed since their origin in the Federal Constitution of 1988 [4]. Academic hiring at public universities is subjected to the same procedures as all public tenders. Since academia is a place for innovation and knowledge production, one of its tasks should be the quest for paradigm changes [5].

The Brazilian National Council for Scientific and Technological Development (CNPq) launched, in 1997, a curricular information system denominated Lattes (CNPq 2018a), in honor of Cesare Lattes, a world-renowned Brazilian physicist [6]. CNPq's aim was to integrate all curricula of people associated 
with the Brazilian scientific community into a single database, through the so-called 'Lattes Curriculum' (also named Lattes CV in this manuscript) [6].

This article aims to describe, analyze, and propose alternatives for two 'obsessions' that obstruct progress of academia in Brazil: the way candidates are assessed in public tenders for faculty positions at public universities and the mandatory Lattes CV. This work is a good fit with the Challenging Academia special issue, as it deals with a controversial topic in academia in Brazil, criticizes the status quo, and attempts to debate this topic in Brazil have not been welcome. Earlier attempts to publish our views in Brazilian journals have not been successful, even though we have always presented this work in the form of an opinion article and with the intention of improving current practice in Brazil, as we strongly believe such an improvement will benefit Brazilian students, faculty members, and society.

The current state of practice for hiring faculty at public universities in Brazil is non-meritocratic for the following reasons: (1) the written exams that form part of the evaluation procedure are standardized tests for which privileged candidates can purchase forms of training [4]; (2) regardless of the extensive and complex procedures for hiring faculty, panel members from inside the faculty can manipulate the outcome [7], and (3) peculiarities of the Brazilian system, such as the use of Lattes CV and the fact that all exams are in Portuguese, make it difficult for foreigners to apply to positions in Brazil [8]. In the authors' opinion, the structure of the public tenders and the use of the Lattes CV platform are seriously jeopardizing Brazil's development and pluralism in science and higher education—two major pillars of society.

\section{Current State of Academic Hiring Procedures at Public Universities in Brazil}

\subsection{Public Tenders for Academic Positions}

The original reason for organizing public tenders for faculty positions in Brazil [7] was to ensure that the process is free of favor, nepotism, and political patronage. A candidate who has been hired in the Brazilian public academic system also has major job security. A study [5] that investigated the public tender assessment criteria for faculty positions in 59 Brazilian federal universities concluded that most employ a written exam, a sample lecture, and CV evaluation. Some include an extra assessment called 'Memorial', typically for full professor positions, where a research project is orally presented. Sample lectures are always optional and are an administrative decision. The written exams cover 1-3 out of 10-20 topics publicly announced prior to the exam [5]. This evaluation is a standardized test, for which the candidate can study to obtain a good grade. The shortcomings of using a standardized test are described in Section 3.1.

Table 1. Weight distribution for distinct public tender assessment criteria found in the literature.

\begin{tabular}{cccccc}
\hline Reference & $\begin{array}{c}\text { Written } \\
\text { Exam (WE) }\end{array}$ & $\begin{array}{c}\text { Oral Exam } \\
(\mathbf{O E})\end{array}$ & $\begin{array}{c}\text { Sample } \\
\text { Class (SC) }\end{array}$ & CV & Memorial (M) \\
\hline I [5] & 0.3 & - & 0.4 & 0.1 & 0.2 \\
\hline II [5] & 0.4 & - & 0.2 & 0.2 & 0.2 \\
\hline III [5] & 0.3 & - & 0.3 & 0.2 & 0.2 \\
\hline IV [5] & 0.5 & - & 0.3 & 0.2 & - \\
\hline V [5] & 0.3 & - & 0.3 & 0.4 & 0.4 \\
\hline VI [9] & 0.2 & - & 0.4 & only PhD degree required & 0.2 \\
\hline VII [10] & 0.4 & - & 0.3 & 0.1 & - \\
\hline VIII [11] & 0.4 & 0.4 & 0.2 & 0.3 \\
\hline IX [7] & 0.2 & 0.3 & 0.2 & - \\
\hline \multicolumn{7}{c}{ Final Score $(F S)$ for each candidate in a public tender } \\
\hline
\end{tabular}


Table 1 shows the different weights that are used to determine the Final Score according to different references. The final score of each candidate is the weighted sum of the partial scores in each type of assessment (typically on a 0-10 scale), see the equation at the bottom of Table 1. For example, the first way (I) a candidate can be ranked, is by counting the written exam as $30 \%$ of the overall score, the sample lecture as $40 \%$, the candidate's CV as $10 \%$, and the "Memorial" (research proposal) as $20 \%$. In most cases, the exams and CV are the most- and least-weighted, respectively. In most academic public tenders there is a qualifying phase, i.e., candidates are first classified, typically based on the written and/or oral exams (sometimes the sample lecture also-e.g., [11]), and only those who score higher than a predetermined minimum proceed to the final stage of the selection process.

\subsection{Use of the Lattes CV Platform}

'Lattes is like an idol, thus requiring to be fed every day' [12] perfectly and partially reflects the prevalent environment in Brazilian public universities. 'Perfectly' because Lattes CV has become almost an obsession for important sectors within academia (including private institutions) - e.g., it's a key element in selection processes for research funding or academic positions, and most public tenders for faculty positions recommend or require its use. 'Partially' because there is a reasonable number of full-time professors who have a stable career and do not show any interest in updating their profile. Dias et al. [13] published a histogram of the number of Lattes CVs, among 4,156,635 (one per person) published by 5 April 2015, last updated on each date in 1997-2015. Roughly $60 \%$ and $40 \%$ of the curricula were not updated during the last 1.25 and 2.25 years, respectively, which reveals that either the scientific productivity of those professionals is low, and/or Lattes CV is not effective enough to be the first choice for those users.

\section{Analysis of Current Procedures}

\subsection{Brazilian Public Tenders for Faculty Positions}

According to Fontainha [14], individual success or failure in public tenders depends on the applicant's capacity to adapt to the type of assessment employed. For the hiring procedures in Brazil, the success of a candidate depends on how well he/she/they performs on (written and oral) standardized tests. Fontainha et al. [15] showed that public tenders are used to select people who are neither the most experienced nor the most qualified. Indeed, this reality is not surprising when one realizes the dimension of the editorial and digital markets involved in the preparation of public tender candidates, as described next. Besides, Downie [8] noted that the fact that the exams are in Portuguese is also a major barrier to hiring international faculty.

Many public tender-oriented markets in Brazil have shown an increasing growth in recent years. Araújo [4] points out the following books: 'How to pass exams and public tenders' [16] (more than 200,000 copies sold), 'How to study for public tenders' [17], and the 'Manual for public tender attendees: the path of common people' [18]. On social media, there is an interactive online platform [19] to help prepare for public tenders, which has more than 100,000 members. Searching for 'concurso público Brasil' ('public tender Brazil') on YouTube (12 August 2018) returned 24 videos with more than 200,000 views and five videos with more than 1 million views. In terms of YouTube channels, a search on 'como passar em concurso público' (how to be approved in a public tender), returned 17 channels with more than 30,000 subscribers, 10 channels with more than 100,000 subscribers, four channels with more than 450,000 subscribers, and two channels with more than 700,000 subscribers.

As mentioned before, the hiring decisions are heavily influenced by the exam grades of the candidate. Since the CV does not drive the hiring procedures (or only in a very limited amount of cases, see Table 1), candidates with poor CVs (and perhaps poor scientific performance) have equal chances to be hired as their counterparts who outperform them in terms of scientific productivity do. Studies suggest that public tenders in Brazil assess candidate's research skills in a very superficial way [5]. This lack of proven research qualities can be quite a hindrance, since a full-time professor's teaching 
load is around $20 \mathrm{~h} /$ week (Ziker measured it to be, on average, $24.5 \mathrm{~h} /$ week [20]); i.e., roughly half of a professor's work time should be dedicated to research. Authors like Morin [21], Serres [22], and Demo [23] have mentioned that it is good practice for any teacher to be able to identify current research within their teaching. In other words, teaching without research results in courses with obsolete content [5]. Recent research findings also show that research quality is positively correlated with teaching quality [24]. It's important to note here that it is research quality, not quantity that enhances teaching quality.

While the goal of the public tenders for academic positions is to hire the best candidate in an impersonal way [7], Araujo details in his ethnography how

"different interest groups act and react in order to maintain their spheres of influence inside this peculiar, strict, law-enforced job-searching scenario."

The ethnography contains details of various instances in which departmental politics and power struggles have influenced the hiring panel, as well as the outcome of the hiring process. The colonial heritage of Brazil and resulting political patronage have strongly influenced society. One could wonder, then, why such elaborate procedures are followed when sometimes the preferred candidate is identified by the internal members of the hiring panel from the beginning.

\subsection{Lattes CV Features}

Several types of ineffective features of Lattes CV (and its online platform) are described next. For a more detailed analysis, showing screenshots of all elements mentioned in this analysis, please refer to the preprint of this work [25].

We first address essential information that cannot be included in Lattes $C V$, or that is not compulsory. The main missing element is contact information: email address, phone number, and/or personal website(s). The only information sometimes provided is a postal address. Additionally, one cannot select more than one scientific field of expertise, which does not serve researchers in multidisciplinary or interdisciplinary topics. An English version of Lattes CV is not always available (compare random profile [26] to [27]). Some journal papers are missing their Digital Object Identifier (DOI), issue number or even title (see, for example, random profile [28] which is missing details for references $[29,30])$.

Next, we describe superfluous features of a Lattes CV. Since a Lattes CV does not impose word count limits on some sections and fields, some profiles become overly long, which makes it difficult for recruiters to extract the most important information (see, for example, randomly selected profile [31]). Additionally, the 'Formal education/Degree' section includes fields such as information from a random profile [32]: (1) Major Area (e.g., 'Linguistics, Letters and Arts'), (2) Area (e.g., 'Letters'), (3) Sub-Area (e.g., 'Literaturas Estrangeiras Modernas'-without English translation), and (4) Specialty (e.g., 'Literatura em Lingua Inglesa' - without English translation). These extra subdivisions clutter the profiles and the same information can be found in the 'keywords'. Lastly, some sections on the CV could be shortened or excluded (e.g., [26]): expanded abstracts and abstracts published in conference proceedings (for most purposes, only full conference papers or presentations are evaluated), participation in examination boards, and academic advisory roles (information could be presented in a more concise form).

The Lattes platform [33] contains a number of software issues that make creating and updating a CV difficult. Selecting an institution requires a number of steps. Multiple entries of the same institution exist, as users are allowed to create institutions. A link between institution and its country is also missing.

Finally, the Lattes platform does not translate well into English. Even though the platform is designed for researchers, many technical terms are not correctly translated into English. One striking error is that abstract is translated as summary (see, for example, profile [26]). For a list of erroneous translations for keywords in civil engineering, refer to the extended analysis in the preprint [25]. 
One feature in the Lattes platform that can be very useful for recruiters (although only available in the Portuguese version, as can be seen in [26]), is the indication per journal publication of the number of citations from the Web of Science (WoS), Scopus, and Scielo databases.

\section{Suggestions for Improvement}

The authors of this manuscript consider the current assessment method of a candidate's knowledge in public tenders and the mandatory use of a Lattes $\mathrm{CV}$ as highly questionable. The examination stage suggests that the candidates' qualifications, experience and skills included in their CVs, all fully proven by institutional certificates, letters of recommendation, and publication metrics, are insufficient. Furthermore, many candidates graduated from the same institution where they are applying for a position, somehow showing that their degree is not sufficient or valid in demonstrating that they are qualified for the position.

As mentioned by Araujo [7], the impact of newly hired faculty on the university is as follows: when the best candidate is hired, this person is expected to have the largest productivity. This, in turn, will be reflected by the amount of funding that goes to research and graduate students. Araujo [7] sums this up as:

"In the long run, students, and not faculty, are impacted, because the amount of public money allocated for grants is related to the productivity of the faculty members. The best option would be to take seriously into account the curriculum vitae of the candidates, and not his/her degree of empathy."

To improve hiring procedures in Brazil, one can analyze best practice manuals from international institutions, for example [34]. The authors' proposal for a suitable selection process in any public tender in academia consists of the following three elements: full CV, interview, and a 15 min sample lecture on a given subject. Literature on recruiting processes in organizations has highlighted that the interview is one of the most effective instruments used [35], and its application in academia is recommended by Bohlander et al. [36]. Kramnick [37] suggests that using Skype interviews can be preferable for two reasons: It does not require the candidate to spend money to travel to the interview and it removes the need for small talk before the actual interview. The need for a travel budget and the ability to feel comfortable in certain social settings may be more accessible to candidates from a privileged background-using videoconferencing may mitigate this implicit hurdle.

A two-tier process, in which first a preselection of suitable candidates is made based on the $\mathrm{CV}$ and a motivation letter, and then suitable candidates are invited for the interview and sample lecture, is recommended. For the interview, it is recommended to start with a short presentation of the candidate's previous experience and major achievements, followed by a discussion on his/her teaching and research goals.

The interview should be taken by a balanced and diverse (with gender and racial diversity where possible) committee, which includes a student, a junior faculty member, a senior faculty member, and an exterior committee member. Any proposed method of evaluation should be analyzed periodically and updated in light of new research findings currently used tools [38].

For CV evaluation in the first assessment round, we propose a weighted formula. The weighted formula should include elements such as scientific performance (e.g., based on citation indexes proposed by Abambres and Arab [39]), and professional experience. The institution where the candidate graduated from can be evaluated for this classification. The professional experience evaluates the work experience of the candidate only. The teaching skills of the candidate will be evaluated separately in the sample lecture. Other elements that can be evaluated and added to the weighted formula, depending on the position, are: scholarships, prizes and other recognitions, service appointments (e.g., technical committees), involvement with professional organizations (or their associated student chapters), and funding obtained during previous positions. The weight to be assigned to each of the categories used to evaluate the candidate's CV can be tailored to the academic position he/she/they are applying for. 
These procedures are recommended to have a better evaluation of the research performance of a candidate, since the new employee will dedicate roughly $50 \%$ of his/her/their time to research, as discussed in Section 3.1. Note that, for a faculty member to dedicate this amount of time to research, it is necessary that sufficient administrative support is available. Whereas globally the trend is to reduce support staff and give more administrative tasks to professors, the authors' opinion is that sufficient administrative staff is necessary for the optimal functioning of faculty.

\section{Discussion}

The analysis in Section 3.2 describes the shortcomings of the Lattes CV platform. In the authors' opinion, Lattes CV should not be imposed as a mandatory CV format in job or funding applications, and most of its features need to be improved to allow its effective use, as described in the previously presented analysis. In order to overcome a crucial drawback, the authors recommend the automatic creation and updating of each CV based on information taken from more effective, popular and renowned platforms such as Microsoft Academic, Google Scholar, ORCID, ResearcherID, or similar. The authors consider that an effective CV should be as short as possible, and easy to read and compare (the same holds for the platform where the CV is built).

Examples that should be followed are Microsoft Academic and Google Scholar, where either references are automatically found and included in one's profile (including a hyperlink to the article's official website), or a hyperlink is automatically created when a reference is manually added to an author's profile. Alternatively, a tool can be programmed (such as Top Academia in Saudi Arabia [40], which crawls the Web of Science database) to collect relevant information from the available bibliometric sources and build a profile for the candidate. As the abilities of scripting for sorting information increase [38], we should make use of such tools yet keep in mind that the procedures should be democratic in the face of standardization.

The feature of showing the number of citations mentioned in Section 3.2 could be introduced into existing platforms (e.g., Microsoft Academic, Google Scholar, Science Open, ResearchGate, ResearcherID, etc), either explicitly, and/or implicitly by providing citation indices per author based on the proposal of Abambres and Arab [39], i.e., weighting the authorship order/credit in each publication, as well as the source (WoS, Scopus, or 'others') of each citation. The advantage of this approach is that it provides a combination of different indexing databases, whereas the current Lattes CV metrics separate the different indexing databases.

As compared to the international state of the practice, we can see that the ideal hiring procedures do not exist yet. We could turn to best-practice manuals from universities in the United States [34], yet need to keep in mind that there is systematic inequality related to prestige in the hiring procedures in the United States [41]. Most universities in Europe mention their hiring procedures on their website. KU Leuven [42] follows a typical hiring procedure of two steps. In the first step, candidates send their $\mathrm{CV}$, a discussion of their five most important publications, and an autobiographical essay. Then, candidates on the shortlist will be invited for an interview, a sample lecture, and/or for sending their publications. Similarly, TU Delft [43] first requires candidates to submit a CV, a research plan, list of publications, and the names and e-mail addresses of at least three potential references along with a letter of application. In a second stage, candidates are invited to give a presentation outlining their research and teaching vision. Similar requirements and a two-step procedure are described by RWTH Aachen [44].

Although currently no ideal hiring procedures exist, we consider it important to highlight the shortcomings of the current state of practice in Brazil, so that Brazilian academia can move towards fairer hiring procedures. As mentioned previously, the main influence on the outcome of the public tenders is on the budget available for graduate students-the students are thus most affected by the hiring decisions, and they currently have no voice in these procedures.

When developing improved methods for hiring faculty in Brazil, we should learn from the experience and the international state of the practice. At the same time, we should consider the unique 
cultural and social aspects of academia in Brazil, as earlier research comparing academia between two countries (United States and the Czech Republic) showed that there is no "one size fits all" at an international level [45]. Lamont [46] also warned against exporting customary rules of evaluation from the United States to an international context.

One issue hiring panels should be aware of, is related to minorities. This problem lies deeper than just our personal biases, as the current status is one of systematic methodological disqualifications of contributions from members of underrepresented social groups [47]. As Saul remarked, this issue directly influences hiring panels:

"[m]any admissions and hiring committees have a commitment to improving gender balance and perhaps even to choosing a woman over an equally qualified man but implicit biases may well prevent them from seeing which women are equally qualified."

As a solution to this deep-rooted problem, Leuschner [47] proposes mechanical methods. In terms of hiring, she proposes a quota for hiring women and shows that affirmative action programs have been and are helpful.

While we have focused in this work on meritocratic procedures (in terms of finding the best candidate for a vacancy, while keeping in mind biases against minorities), we should be aware of the flaws of meritocracy itself. As Leuschner [47] pointed out, meritocracy has resulted in the self-production of elite groups and fails to adhere to pluralistic standards. At its worst, meritocracy is elitist and inequitable, obstructing consent and cohesion in society [48]. Paradoxically, opportunities for merit are themselves determined by non-meritocratic factors (talent is not distributed in a meritocratic way) [49], and the definition of "merit" itself implicitly favors some groups of society over others. Mijs [49] thus argues that meritocracy itself is an unfulfillable promise. Instead, we should strive to adhere to the principles of justice, need and equality in academia. While his analysis focused on higher education, and questions whether universities should train students for the labor market or build character and citizenship, further research seems necessary to identify how the principles of justice, need and equality can also be included during the academic hiring procedures to create a level playing field where bias will not (inexplicitly) affect the hiring procedures.

The comments in the previous paragraphs related to the obstacles minorities face, should be more than "good to know." The guidelines for hiring procedures in Brazil should directly address these challenges, and the mechanical methods proposed by Leuschner [47] could be used in the context of Brazilian academia. From this perspective, the evaluation of a researcher's CV as outlined in Section 4, should also be evaluated from the gender perspective. Nielsen [50] shows that bibliometrics used as a driving factor during hiring procedures perpetuate existing gender inequalities in academia. We should also make sure that reduced productivity during and after maternity leave does not reflect negatively upon the evaluation of the CV of a woman with children (to remove the so-called "motherhood penalty"). His solution is then articulated as follows:

"my suggestion therefore is to always supplement the use of quantitative proxies for merit with in-depth and systematic qualitative considerations about variations in expertise, experience, activities and career progression along gendered lines; even when comparing large numbers of researchers. Such an approach could help render visible some of the potential gender biases related to the use of quantitative performance metrics, hereby making academic recruitment and selection processes less gendered in their stratifying outcomes."

The neoliberal reality of today's university landscape also poses significant limitations to researchers [51,52], which are difficult to evaluate and take into consideration during hiring procedures.

For all good intentions on developing the best hiring procedures, we should keep in mind that human emotions play a role in these procedures [53]. These extra-cognitive emotional aspects of the hiring procedures are not well-known nor researched. We should be aware of these: how they influence how favourably we rate a candidate, and how we could possibly quantify these emotional aspects. Again, this knowledge could be used in the future to improve hiring procedures. 
Based on the investigation carried out and the authors' professional experiences, it is no surprise that the Brazilian academic market is still inward-oriented, even though most universities have developed stronger links with foreign institutions. A limited number of foreign students and professionals (especially from outside Latin America) [8] work at Brazilian universities, and Brazilian scientists still [54] publish a significant amount of work in national journals, which sometimes are only available in Portuguese. By limiting its capacity to attract foreign talent, Brazilian academia fails not only to identify the most suitable (national or international) candidates, but also to promote diversity and pluralism.

\section{Conclusions}

This paper describes two major flaws in Brazilian academia-the pseudo-meritocratic public tender and the Lattes CV. The public tender, with its standardized written exam, makes the hiring procedures for faculty in Brazil unnecessarily complex, resulting in a system where one can study to pass the exam and have a good "grade" in the tender, and yet is not immune for realpolitik within the hiring committees itself. We propose to replace the current hiring procedures by procedures similar to those used in an international context: a two-tier approach where the CV and application letter is first analyzed, and then the candidates are invited for an interview and short sample lecture.

A second particularity of academia in Brazil is the use of the Lattes CV platform. The Lattes CV is the only CV that counts when a candidate applies for a position, or even when applying for funding. Our proposal is simply to use a regular CV instead of the convoluted Lattes platform. If Brazilian universities find an online profile necessary, then popular online platforms such as Microsoft Academic, Google Scholar, ORCID or ResearcherID could be used.

With the recent budget cuts in Brazil, we consider that the time is right for change. The convoluted hiring processes in Brazil and their self-engineered, self-funded, and self-maintained Lattes CV platform may be eating away at a budget that could be redirected to scholarships for students, used for opening more faculty positions, or used for funding research. Meanwhile, the time is right to ask ourselves critical questions: what can we do to improve hiring procedures in such a way that minorities are not affected by implicit biases in academia and hiring panels? How can we use affirmative actions that have worked elsewhere in the world within the social context of Brazil? Ultimately, what type of faculty does Brazil need in order to be a reflection of its society, so that faculty members can address the needs of the Brazilian society on one hand, and have a voice in an international context as well.

Even though the lack of research funding in Brazil is the most discussed topic in the media, increasing funding is not the only solution Brazilian academia needs to thrive in an international context. We hope that we have provided a relevant contribution for Brazil to prosper academically and scientifically in the near future, and that the questions we address in this work within the Brazilian context will also help our colleagues internationally to think further about the hiring procedures at their institutions.

Author Contributions: Conceptualization and first-draft writing (preprint [25] only): M.A.; Validation, manuscript handling and revised versions: E.O.L.L.; All other contributions: equally distributed among all authors.

Funding: This research received no external funding. The APC was funded by the Open Access program of TU Delft.

Conflicts of Interest: The authors declare no conflict of interest.

\section{References}

1. Barbosa, L. Meritocracia à brasileira: O que é desempenho no brasil? Rev. Serviço Público 1996, 120, 58-102.

2. Pinheiro, J. Brazil Is a Flawed Meritocracy in More Ways than Just One. Available online: https://www1.folha.uol.com.br/internacional/en/brazil/2018/05/1967769-brazil-is-a-flawed-meritocracy-inmore-ways-than-just-one.shtml (accessed on 5 August 2018). 
3. Fan, J. A Brazilian Thriller that Exposes the Sinister Side of Meritocracy. Available online: https://www.newyorker.com/culture/cultural-comment/a-brazilian-thriller-that-exposes-the-sinisterside-of-meritocracy (accessed on 5 August 2018).

4. Araújo, H.N.T. A Construção do Ethos Concurseiro: Mérito e Experiência Moral na Competição por Cargos Públicos; Federal University of Paraiba: João Pessoa, Brazil, 2016.

5. Siqueira, E.S.; Binotto, E.; Silva, F.M.V.D.; Hoff, D.N. Seleção de docentes em universidades federais: Uma análise dos regulamentos. Ens. Avaliação Políticas Públicas Educ. 2012, 20, 725-748. [CrossRef]

6. Mena-Chalco, J.P.; Cesar Junior, R.M. Scriptlattes: An open-source knowledge extraction system from the lattes platform. J. Braz. Comput. Soc. 2009, 15, 31-39. [CrossRef]

7. Araujo, A.G.D.M. An ethnography of academic job position-filling: The case of the brazilian "concursos". Preprint 2019.

8. Downie, A. Brazilian Universities Find Challenges in Internationalization. Available online: https://www. chronicle.com/article/Brazilian-Universities-Find/124312 (accessed on 6 March 2019).

9. Governo do Estado de São Paulo (GESP). Diario Oficial. Diário Of. 2018, 128, 233.

10. Imprensa Nacional. Diario Oficial. Diário Of. 2018, 87, 1-274.

11. Fundação Universidade de Brasília (FUB/UnB). Edital de abertura de concurso público docente n. 17 de 22/01/2018; Fundação Universidade de Brasília: Brasília, Brasil, 2018.

12. Bertonha, J. Produção e produtividade no meio acadêmico: A "ditadura do lattes" e a universidade contemporânea. Rev. Espaço Acadêmico 2009, 100, 6-9.

13. Dias, T.M.R.; Moita, G.F.; Dias, P.M. Adoção da plataforma lattes como fonte de dados para caracterização de redes científicas. Encontros Bibli 2016, 21, 11. [CrossRef]

14. Fontainha, F.C. Meritocracia e concursos públicos. Insight Inteligência 2013, XVI, 52-66.

15. Fontainha, F.C.; Geraldo, P.H.B.; Veronese, A.; Alves, C.S.; Figueiredo, B.H.; Waldburger, J. Processos Seletivos Para a Contratação de Servidores Públicos: Brasil, o País dos Concursos? Fundação Getulio Vargas (FGV Direito Rio): Rio De Janeiro, Brazil, 2014.

16. Douglas, W. Como Passar em Provas e Concursos, 29th ed.; Impetus: Rio de Janeiro, Brazil, 2015.

17. Meirelles, A. Como Estudar Para Concursos, 4th ed.; Juspodivm: Salvador, Brazil, 2017.

18. Viegas, A. Manual de um Concurseiro: O Caminho Das Pessoas Comuns, 6th ed.; Método: São Paulo, Brazil, 2010.

19. Bulletin Solutions, I. Fórum Concurseiros. Available online: http://www.forumconcurseiros.com/forum/ forumd (accessed on 3 September 2018).

20. Ziker, J. The Long, Lonely Job of Homo Academicus-Focusing the Research Lens on the Professor's Own Schedule. Available online: https://thebluereview.org/faculty-time-allocation/ (accessed on 6 March 2019).

21. Morin, E. Introdução ao Pensamento Complexo; Instituto Piaget: Lisboa, Portugal, 1990.

22. Serres, M. Filosofia Mestiça: Le Tiers Instruit; Nova Fronteira: Rio de Janeiro, Brazil, 1993.

23. Demo, P. Avaliação Sob o Olhar Propedêutico; Papirus: São Paulo, Brazil, 1996.

24. Cadez, S.; Dimovski, V.; Zaman Groff, M. Research, teaching and performance evaluation in academia: The salience of quality. Stud. High. Educ. 2017, 42, 1455-1473. [CrossRef]

25. Abambres, M.; Ribeiro, T.; Sousa, A.; Lantsoght, E.O.L. Ineffective obsessions in brazilian academia and proposals towards meritocracy. OSF PREPRINTS 2018. Available online: https://osf.io/3n4re/ (accessed on 4 September 2018). [CrossRef]

26. Barham, E. Elizabeth Joan Barham's Lattes cv. Available online: https://archive.is/37K6s (accessed on 4 September 2018). (In English).

27. Marchesi, I.M. Isadora moraes marchesi's lattes cv. Available online: https://archive.fo/189pB (accessed on 3 September 2018).

28. Missau, F.C. Fabiana Cristina Missau's Lattes cv. Available online: https://archive.fo/ILM4p (accessed on 3 September 2018).

29. Pizzolatti, M.G.; Mendes, B.G.; Soldi, C.; Missau, F.C.; Bortoluzzi, J.H.; Carasek, E. Analysis of volatile compounds released from flowers and roots of polygala cyparissias and polygala paniculata by headspace/spme. J. Essent. Oil Res. 2009, 21, 255-258. [CrossRef]

30. Franco, J.L.; Braga, H.C.; Stringari, J.; Missau, F.C.; Posser, T.; Mendes, B.G.; Leal, R.B.; Santos, A.R.S.; Dafre, A.L.; Pizzolatti, M.G.; et al. Mercurial-induced hydrogen peroxide generation in mouse brain mitochondria: Protective effects of quercetin. Chem. Res. Toxicol. 2007, 20, 1919-1926. [CrossRef] 
31. Kiill, C.P. Charlene Priscila Kiill's Lattes cv. Available online: https://archive.fo/6VfA5 (accessed on 4 September 2018).

32. Miguel, A.D. Alcebiades Diniz Miguel's Lattes cv. Available online: https://archive.fo/h5NEm (accessed on 4 September 2018).

33. Conselho Nacional de Desenvolvimento Científico e Tecnológico (CNPq). Plataforma lattes—cadastrar novo currículo. Available online: https://archive.fo/9ZHGY (accessed on 3 September 2018).

34. Columbia University. Guide to Best Practices in Faculty Search and Hiring; Columbia University: New York, NY, USA, 2016.

35. Limongi-França, A.C. Práticas de Recursos Humanos_PRH; Atlas: São Paulo, Brazil, 2007.

36. Bohlander, G.; Snell, S.; Sherman, A. Administração de Recursos Humanos; Pioneira Thomson Learning: São Paulo, Brazil, 2003.

37. Kramnick, J. The Way We Hire Now. Available online: https://www.chronicle.com/article/The-Way-We-HireNow/244467 (accessed on 6 March 2019).

38. Lamont, M. Toward a comparative sociology of valuation and evaluation. Annu. Rev. Sociol. 2012, 38, 201-221. [CrossRef]

39. Abambres, M.; Arab, P. Citation indexes accounting for authorship order in coauthored research-review and new proposal. Sci. Technol. Libr. 2016, 35, 263-278. [CrossRef]

40. Al-Rasheid, K.A.S.; Al-Farhan, A.; Al-Qurashi, S.; Abdullah, I.; Al-Mosawi, M. Top academia: Development of a system for evaluation of staff, departments and colleges in king saud university. Geomat. Inf. Sci. Wuhan Univ. 2010, 35, 22-28.

41. Clauset, A.; Arbesman, S.; Larremore, D.B. Systematic inequality and hierarchy in faculty hiring networks. Sci. Adv. 2015, 1, e1400005. [CrossRef]

42. KU Leuven. Senior Academic Staff E Tenure Track: Informatie; KU Leuven: Leuven, Belgium, 2019.

43. TU Delft. Working at tu Delft; TU Delft: Delft, The Netherlands, 2019.

44. RWTH Aachen. Professorships; RWTH Aachen: Aachen, Germany, 2019.

45. Preiss, M.; Klein, H.A.; Levenburg, N.M.; Nohavova, A. A cross-country evaluation of cheating in academia-A comparison of data from the us and the czech republic. J. Acad. Ethics 2013, 11, 157-167. [CrossRef]

46. Lamont, M. Revisiting "how professors think" across national and occupational contexts. Rev. Sociol. 2013, 98, 5. [CrossRef]

47. Leuschner, A. Social exclusion in academia through biases in methodological quality evaluation: On the situation of women in science and philosophy. Stud. Hist. Philos. Sci. Part A 2015, 54, 56-63. [CrossRef]

48. Littler, J. Against Meritocracy: Culture, Power, and Myths of Mobility; Routledge: London, UK, 2017.

49. Mijs, J.J.B. The unfulfillable promise of meritocracy: Three lessons and their implications for justice in education. Soc. Justice Res. 2016, 29, 14-34. [CrossRef]

50. Nielsen, M.W. Scientific performance assessments through a gender lens - a case study on evaluation and selection practices in academia. Sci. Technol. Stud. 2018, 31, 2-30.

51. Richter, M.; Hostettler, U. Conducting commissioned research in neoliberal academia: The conditions evaluations impose on research practice. Curr. Sociol. 2015, 63, 493-510. [CrossRef]

52. Cannizzo, F. Tactical evaluations: Everyday neoliberalism in academia. J. Sociol. 2018, 54, 77-91. [CrossRef]

53. Lamont, M. Book review: How professors think: Inside the curious world of academic judgment. Rev. Esp. Investig. Sociol. 2012, 140, 173-177.

54. Glänzel, W.; Leta, J.; Thijs, B. Science in brazil. Part 1: A macro-level comparative study. Scientometrics 2006, 67, 67-86. [CrossRef]

(C) 2019 by the authors. Licensee MDPI, Basel, Switzerland. This article is an open access article distributed under the terms and conditions of the Creative Commons Attribution (CC BY) license (http://creativecommons.org/licenses/by/4.0/). 